\title{
Production of Bio-Pellet Briquettes From Coconut Shell Waste as Alternative Energy for Household Scale
}

\author{
Muhammad Yerizam ${ }^{1, *}$ Muhammad Zaman ${ }^{1}$ Taufiq Jauhari ${ }^{1}$ Nur Yuli ${ }^{1}$ Riwen \\ Setiawan ${ }^{1}$ Umaidella Affrilla ${ }^{1}$ \\ Chemical engineering, Politeknik Negeri Sriwijaya, Jl. Srijaya Negara, Bukit Besar, Palembang 30139, Indonesia \\ *Corresponding author. Email:yerizam@polsri.ac.id
}

\begin{abstract}
Biomass is a renewable energy material because it can be produced quickly however, biomass has the disadvantage of being burned directly because of its poor physical properties, such as low energy density, handling, storage and transportation problems. To improve the quality of biomass combustion, biomass fuel in the form of pellets is developed, known as bio-pellet. Bio-pellet was developed as an alternative fuel derived from wood dust. One of the materials that can be converted into briquette bio-pellet is coconut shell. This study aims to determine the effect of coconut shell bio-pellets by using different temperature variations according to SNI standards. Making biopellet from coconut shell raw materials with variations in temperature parameters, namely $300^{\circ} \mathrm{C}, 400^{\circ} \mathrm{C}, 500^{\circ} \mathrm{C}$, and $600^{\circ} \mathrm{C}$ with a constant time of 1 hour. The adhesive used is tapioca flour with a concentration of $10 \%$. 3. From the results of the study, it can be seen that the best quality of bio-pellet is in terms of temperature variation, that is, the curing temperature parameter is $500^{\circ} \mathrm{C}$ and 1 hour of cooking time with $10.58 \%$ moisture content, $11.03 \%$ ash content, $30.01 \%$ volatile matter content, the fixed carbon content is $48.38 \%$, and the calorific value is $6564.88 \mathrm{cal} / \mathrm{g}$ because it is sufficient to meet the SNI 8021-2014 bio-pellet standards and several other standards.
\end{abstract}

Keywords: Bio-pellet, Coconut shell, Carbonization

\section{INTRODUCTION}

Waste is often defined as waste material or residual material from the processing of agricultural products. The process of destroying waste is naturally slow, so that the waste not only disturbs the surrounding environment but can further harm human health. The paradigm of mentioning this waste must be changed because human knowledge is not yet developed. Agricultural waste materials such as biomass can be processed as an alternative energy source which has high value. Biomass has potential as an alternative fuel to replace fossil fuels due to the high carbon content of biomass. Biomass was chosen as an alternative energy source because of its renewable nature, in addition to its abundant availability and low price.

Coconut shell biomass is a type of biomass that is widely produced in Indonesia and has not been widely used. Coconut shell biomass is produced from coconut plants. The total area of coconut trees in 2015 reached $3,585,600$ hectares, with a total production of 2,920,700 tons (BPS, 2017). The average annual production of coconut fruit is 3.03 million tons, so there are 350,484 tons of coconut shells produced annually. The production of such a large coconut shell has not been utilized optimally. The large number of small industries and households that use coconut as a basic ingredient has resulted in increased coconut shell waste because it has not been utilized properly.

Biomass can be used as fuel directly as has been done by the Indonesian people for a long time, but biomass has weaknesses if it is burned directly because of its poor physical properties, such as low energy density, handling, storage and transportation problems (Saptoadi, 2004). To improve the quality of biomass combustion, currently, biomass fuel in the form of pellets has been developed, known as bio-pellet. Biopellet was developed as an alternative fuel derived from wood dust. Research that examines the formulation of coconut shell charcoal to be effective and efficient, both from an economic point of view and the results of its combustion has been carried out by $\mathrm{M}$. Tirono and Ali Sabit (2011). This study analyzes the effect of variations in carbonization on the calorific value of coconut shell 
charcoal. The results showed that the calorific value was directly proportional to the high coking temperature.

Therefore, it is necessary to carry out further research in the form of making briquette biopellets by utilizing agricultural waste materials, namely coconut shell biomass to improve the quality of the research products above, by carrying out carbonization processes and different treatments, these biopellets can be used as fuel for household needs and lighters. in combustion, because its smaller size is also an economical price.

\subsection{Theoretical Review}

\subsubsection{Bio-pellet}

Bio-pellet is a pellet-shaped biomass fuel that has uniformity in size, shape, humidity, density and energy content (Abelloncleanenergi, 2009). The main advantage of using biomass bio-pellet fuel is the reuse of waste materials such as sawdust which are usually thrown away. Wood dust that is just wasted can be oxidized under uncontrolled conditions to form methane or greenhouse gases (Cook, 2007). In addition, according to PFI (2007), pellets have consistency and fuel efficiency that can produce lower emissions than wood. Pellet fuel produces the lowest particulate emissions compared to other types. The standard of biopellet quality is based on SNI 8021-2014.

\subsubsection{Coconut shell}

Coconut shell is part of the coconut fruit whose function is to protect the core of the fruit biologically and is located on the inside of the coir with a thickness ranging from 2-6 mm. Coconut shell is categorized as hardwood with a moisture content of about 6-9\% (calculated based on dry weight.).

\subsubsection{Carbonization}

Biomass carbonization is a combustion process at high temperature to increase the calorific value of biomass, so the result is charcoal which is composed of carbon and black. In general, this process is carried out at a temperature of $500-800 \mathrm{oC}$, the volatile substance content will be lost so that the initial pore structure will be formed (Widowati, 2003). Carbonization can also be said as a process to convert organic matter into charcoal. In the carbonization process, there will be a process of releasing or evaporating flammable substances such as $\mathrm{CO}, \mathrm{CH} 4, \mathrm{H} 2$ formaldehyde, formic and acetyl acid as well as non-combustible substances such as $\mathrm{CO} 2, \mathrm{H} 2 \mathrm{O}$ and liquid tar. The gases released in this process can be used to meet heat requirements in the carbonization process.

\section{METHOD}

\subsection{Research Date and Time}

The research was carried out for 1 month, namely May 2020 which was carried out in the hydrocarbon laboratory of the Chemical Engineering Department of the Sriwijaya State Polytechnic of Palembang.

\subsection{Research Tools and Materials}

The ingredients used are coconut shell and tapioca flour. The tools used in this research are furnace, milling machine, sieve, analytical balance and pellet press.

\subsection{Treatment and Research Plans}

\subsubsection{Treatment}

In bio-pellet-making research there are variables that can be taken including fixed variables and nonfixed variables. Fixed variables in the form of authoring time, adhesive concentration and mesh value. While the non-permanent variable taken is the authoring temperature or carbonization.

\subsubsection{Experimental Design}

This study aims to determine the effect of coconut shell bio-pellet by using different temperature variations in accordance with SNI standards.

\subsubsection{Procedure}

This research consists of several stages, namely raw material preparation, carbonization, milling, enrichment, dough making, and printing. Preparation of raw materials includes drying of coconut shell raw material in the sun and cleaning of coconut shell from fiber etc. Then the coconut shell is carbonized at temperature variations of $300,400,500$ and $600 \mathrm{oC}$. The charcoal obtained was then ground and sifted using a sieve with a size of 60 mesh. Then the powder is mixed with $10 \%$ tapioca adhesive and printed with a bio-pellet printer

\section{RESULTS AND DISCUSSION}

\subsection{Effect of Temperature on Fixed Carbon Levels}

From Figure 3.1 the bound carbon content has met the quality standards for biopellets based on the National Standardization Agency (BSN) and SNI 80212014, this can be seen in Figure 3.1 which shows the relationship between temperature and fixed carbon levels.

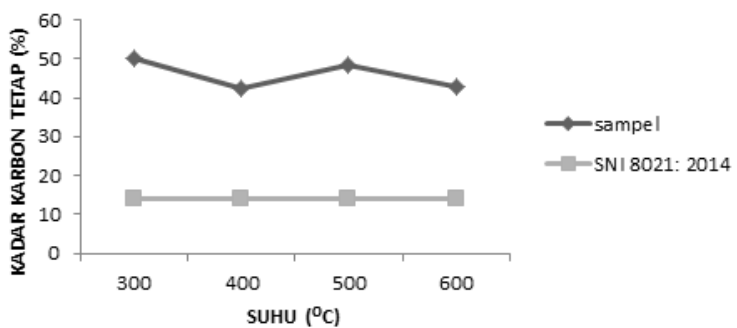

Figure 3.1 Effect of Temperature on Fixed Carbon Rate 
Based on the research results, the fixed carbon content obtained ranged from 42.27\% - 50.22\%. The lowest carbon content was found in bio-pellet with a temperature of $400{ }^{\circ} \mathrm{C}$ of $42.27 \%$. While the highest carbon content was found in bio-pellets with a temperature of $300^{\circ} \mathrm{C}$ at $50.22 \%$. This shows that the temperature variation of $300{ }^{\circ} \mathrm{C}$ is the best variation based on the content of the bound carbon, this level will later affect the calorific value of the bio-pellet because the greater the carbon content bound to the bio-pellet the greater the heating value (Sulistyowati, 2010). The results of this study are in line with the research of Pari and Sailah (2001) which states that the value of bound carbon is influenced by the high and low ash content and the level of volatile matter produced.

\subsubsection{Effect of Temperature on Ash Content}

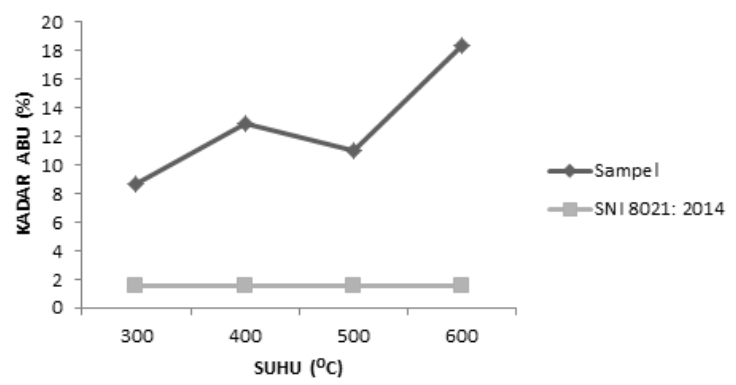

Figure 3.2 Effect of Temperature on Ash Level

The analysis results, the ash content obtained ranged from $8.67 \%-18.36 \%$. The results of the ash content test with various temperature variations of $300^{\circ}$ $\mathrm{C}, 400{ }^{\circ} \mathrm{C}, 500^{\circ} \mathrm{C}$ and $600^{\circ} \mathrm{C}$ on the bio-pellet showed that the bio-pellet with a temperature of $600^{\circ} \mathrm{C}$ had the highest ash content, namely $18.36 \%$. While the lowest ash content is at a temperature of $300{ }^{\circ} \mathrm{C}$ at $8.67 \%$. Overall, the ash content contained in each biopellet did not meet the Indonesian National Standard (SNI), which exceeds the maximum limit of $1.5 \%$. According to Iswandaru (1994), the ash content is influenced by the type of raw material, because the amount of minerals for each type of raw material is different. Coconut shells as well as oil palm shells have a high silica content (Usman, et al., 2014).

This shows that the type of raw material has a significant effect on the resulting ash content. Another possibility is caused by an imperfect carbonization process. According to Yoyon, Bambang, Herwindo, and Ja'far (2011), the high ash content obtained is due to the incomplete carbonization process, namely the amount of air that enters so that the charcoal formed turns into ash. Ash is an unwanted component in the combustion process (Ramsay, 1982) because it can reduce combustion efficiency (El Bassam and Maegaard, 2004). The use of pellets for household fuel, the pellets must have low levels of flying substances so as not to cause pollution. The higher the level of flying substance in a fuel, the fuel combustion efficiency will decrease and the more smoke will be produced (Nurwigha 2012).

\subsubsection{Effect of Temperature on Volatile Matter Rate}

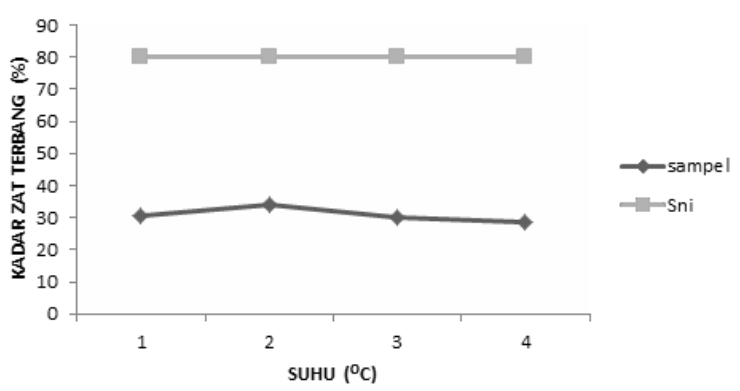

Figure 3.3 Effect of Temperature on Levels of volatile matter

Based on the results of the study, the levels of volatile matter obtained ranged from $28.48 \%-33.81 \%$. The greater the heating temperature of the bio-pellets, the smaller the flying substance content, this is evidenced by Liliana (2010) which states that the carbonization of rice husks aims to reduce levels. Volatile matter substances cause smoke and increase the calorific value of combustion. The heating process at high temperatures reduces the volatil metter content, because volatile matter can only be removed at high temperatures. While in this study the highest value for volatile mattaer levels was found in bio-pellets with a temperature variation of $400{ }^{\circ} \mathrm{C}$ of $33.81 \%$ and the lowest was in bio-pellets with a temperature variation of $600{ }^{\circ} \mathrm{C}$ of $28.48 \%$. The use of biopellets for household fuel, pellets must have low levels of flying substances so as not to cause pollution. The higher the level of volatile matter in a fuel, the fuel combustion efficiency will decrease and the more smoke will be produced (Nurwigha 2012). The flight substance level value meets SNI 8021-2014 which requires that the maximum volatile matter content value is $80 \%$.

\subsubsection{Effect of Temperature on Water Content}

From Figure 3.4 the water content has met the biopellet quality standards based on the National Standardization Agency (BSN) and SNI 8021-2014, this can be seen in Figure 3.4 which shows the relationship between temperature and water content. 


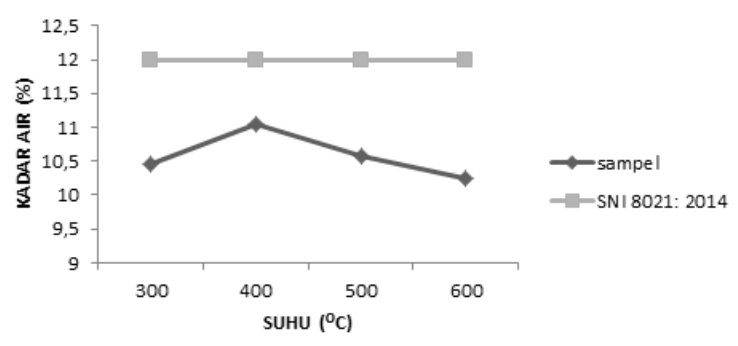

Figure 3.4 Effect of Temperature on Water Content

The value of the water content of the bio-pellet in this study was obtained between 10.24 and $11.05 \%$. The value of water content tends to be high due to the uneven printing or mixing of the adhesive and results in a non-uniform bio-pellet so that it is easy to absorb water in the air. Another factor in making bio-pellet using a mixture of water and adhesive can affect the increase in the water content of the bio-pellet so that the bio-pellet content is unstable. In line with the results of the study, Ali and Restuhasi (2010) stated that the water added during the mixing process of picung cake and additional ingredients has an effect on increasing the water content of bio-pellets. The adhesive factor also plays an important role in increasing the water content of bio-pellets. According to Zamirza (2009) the use of adhesive does not exceed $5 \%$ because the greater the addition of adhesive, it will result in an increase in the water content of the bio-pellet. The high water content in the briquettes makes the calorific value lower and the rate of combustion, this is because during the briquette combustion process it releases more heat to evaporate water (Onu, et al, 2010).

\subsubsection{Effect of Temperature on Heating Value}

The calorific value is an important parameter in determining the quality of fuel which is influenced by moisture content, ash content and bound carbon content. The lower water content and ash content will increase the calorific value of the fuel (Lehtikanges, 2001). Liliana (2010) states that bio-pellets have a minimum calorific value of $4036 \mathrm{kcal} / \mathrm{kg}$, according to American, Austrian, German and French standards.

Based on the results of the study, the calorific value of the bio-pellets ranged from $5941.73 \mathrm{cal} / \mathrm{gr}$ to $6564.88 \mathrm{cal} / \mathrm{gr}$. The resulting calorific value has met the pellet quality standard based on the National Standardization Agency (BSN) and SNI 8021-2014. The calorific value affects the heating temperature. The greater the temperature causes an increase in calorific value because the water content, ash and Volatile matter decrease.

Based on the results of the analysis of the calorific value, it shows that the temperature parameter has a significant effect on the calorific value of the bio-pellet. The temperature variation of $500{ }^{\circ} \mathrm{C}$ is the most optimum condition because it can produce the highest heating value, which is $6564.88 \mathrm{cal} / \mathrm{g}$, while the biopellet with a temperature parameter variation of $400^{\circ} \mathrm{C}$ produces the lowest calorific value of $5941.73 \mathrm{cal} / \mathrm{g}$, apart from that., the previous test results also greatly affect the calorific value, it can be seen in the previous discussion, which shows that the fixed carbon content is influenced by the ash content and the volatile matter content, so the calorific value is the final part of the previous tests, if the fixed carbon content is high then the calorific value also high, this also means that the greater the calorific value, the moisture content, ash content, and volatile matter content must also be low, if seen from the analysis results show that with the highest fixed carbon content of $50.22 \%$ produces a calorific value with a value of $6028,22 \mathrm{cal} / \mathrm{gr}$, this shows a perpendicular correlation between fixed carbon and heating value.

The relationship between temperature and heating value can be seen in Figure 3.5.

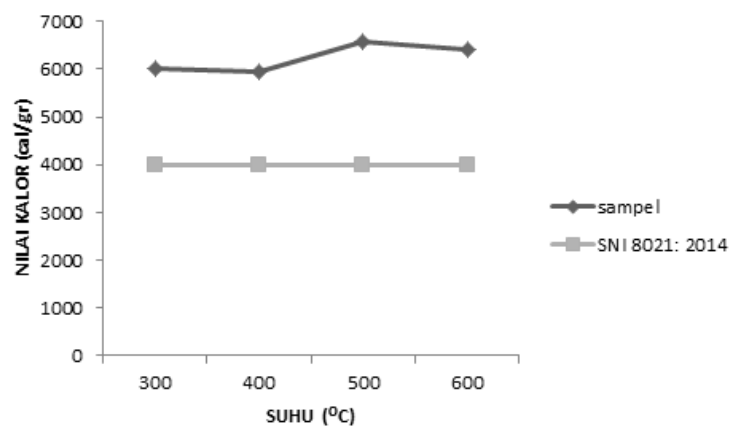

Figure 3.5 Effect of Temperature on Calorific Value

\section{CONCLUSION}

The briquette bio-pellet from coconut shell waste meets the Indonesian national standard based on SNI 8021: 2014 except for the results of the ash content analysis. This is in accordance with the theory which states that the ash content increases with increasing levels of starch adhesive used and the ash content is proportional to the content of inorganic materials contained in the bio-pellet.

From the analysis process, it can be seen that the temperature and the amount of adhesive used in the manufacture of briquette bio-pellet can affect the quality of the bio-pellet produced, the higher the charring temperature with a constant time, the higher the calorific value obtained.

From the results of the study, it can be seen that the best quality of bio-pellet in terms of temperature variation is the parameter variation of coking temperature of $500{ }^{\circ} \mathrm{C}$ and 1 hour of coking time with $10.58 \%$ moisture content, $11.03 \%$ ash content, $30.01 \%$ volatile matter content. , bound carbon content of 
$48.38 \%$, and calorific value of $6564.88 \mathrm{cal} / \mathrm{g}$ because it is sufficient to meet the SNI 8021-2014 bio-pellet standards and several other standards.

\section{REFERENCES}

[1] Abelloncleanenergy. 2009. Cofiring with biopellets: An efficient way to reduce greenhouse greenhouse gas emissions.

[2] Ali, A., \& Restuhadi, F. 2010. Optimasi pembuatan bio-pellet dari bungkil picung (Pangium edule Reinw.) dengan penambahan solar dan perekat tapioka. Sagu, 9(1), 1-7.

[3] [BPS] Biro Pusat Statistik. 2017. Luas Areal Tanaman Perkebunan Rakyat Menurut Jenis Tanaman.

[4] Cook, A. 2007. Efficiency and Economic Advantages of Bulk Delivery of Biomass Pelet Fuel for Space Heating. Pelet Fuels Institute. Arlington, Virginia.

[5] El Basam N, Maegaard P. 2004. Integrated renewable energy on rural communities planning guidelines, technologies and applications. Elsevier. Amsterdam.

[6] Iswandaru. 1994. Pengaruh Waktu Pengarangan dan Kadar Perekat Sagu Terhadap Sifat Kimia Briket Arang Tandan Buah Kosong Kelapa Sawit. (Skripsi): Fakultas Pertanian, Universitas Tanjungpura. Pontianak.

[7] Lehtikangas P. 2001. Quality properties of pelletised sawdust, logging residues and bark. Biomass and Bioenergy 20(5): 351360.

[8] Liliana W. 2010. Peningkatan kualitas biopellet bungkil jarak pagar sebagai bahan bakar melalui teknik karbonisasi[tesis].Bogor: Progam Pascasarjana,Institut Pertanian Bogor.

[9] M. Tirono \& Ali Sabit, 2011. Efek Suhu Pada Proses Pengarangan Terhadap Nilai Kalor Arang. Penelitihan, Jurnal Neutrion vol. 3. No . 2, Jakarta

[10] Nurwigha R. 2012. Pembauatan Bio-pellet Dari Cangkang Kelapa Sawit Dengan Penambahan Arang Cangkang Sawit dan Serbuk Sawit Sebagai Bahan Bakar Alternatif Terbarukan. Fateta. IPB. Bogor.

[11] Onu, F., Sudarja, dan M. B. N. Rahman. 2010. Pengukuran Nilai Kalor Bahan Bakar Briket Arang Kombinasi Cangkang Pala
(Myristica fragan Houtt) dan Limbah Sawit (Elaeis guinensis). Seminar Nasional Teknik Mesin UMY. Yogyakarta

[12] Pari dan Sailah. 2001. Pembuatan Arang Aktif Dari Sabut Kelapa Sawit Dengan Bahan Pengaktif $\mathrm{NH} 4 \mathrm{HCO} 3$ dan (NH4)2 CO3 Dosis Rendah. Jurnal Penelitian Hasil Hutan Bogor. Vol. 19 No 4 : 231- 244.

[13] [PFI] Pellet Fuel Institute. 2007 Pellets: Industry Specifics.http://www.peletheat.org/3/indu stry/IndustrySpecifi cs.html.

[14] Ramsay WS. 1982. Energy from Forest Biomass. New York (US): Academis Press, Inc.

[15] Saptoadi, H., 2004. The Best Composition of Coalbiomass Briquette. A Two Day Collaboration Workshop On Energy, Environtmental, and New Trend In Mechanical Engineering, Department of Mechanical Engineering Brawijaya University, Keio University.

[16] SNI 8021:2014. (2014). Pelet Kayu. Jakarta: Badan Standarisasi Nasional.

[17] Sulistyowati A. 2010. Kualitas Briket Arang Berdasarkan Komposisi Bahan Baku dan Ukuran Serbuk. Untan. Pontianak.

[18] Usman, E., I. Isa, M. Paputungan. 2014. Karakterisasi Briket Campuran Arang Tempurung Kelapa dan Serbuk Kayu Gergaji sebagai Bahan Bakar Alternatif Ramah Lingkungan. KIM Fakultas Matematika dan IPA, 2(2): tanpa halaman.

[19] Widowati, S. 2003. Prospek Tepung Sukun Untuk Berbagai Produk Makanan Olahan dalam Upaya Menunjang Divertifikasi Pangan. Makalah Pribadi pengantar ke Falsafah Sains. Program Sarjana S3. Institut Pertanian Bogor. Bogor

[20] Yoyon S., Bambang., Herwindo, dan Ja'far. 2011. Pembuatan Arang Briket dari Serbuk Gergaji Dengan Proses Pengepresan. Balai Penelitian dan Pengembangan Industri Kalimantan Barat. Pontianak

[21] Zamirza F. 2009. Pembuatan Bio-pellet dari Bungkil Jarak Pagar (Jathropa curcas L.) Dengan Penambahan Sludge Dan Perekat Tapioka. (Skripsi): Fakultas Teknologi Pertanian IPB. Bogor. 